\title{
JUURNAL.RU
}

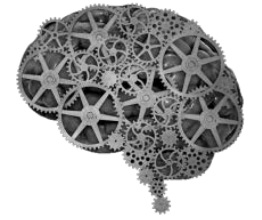

COMPANY GROUP "INTELLEKT"

\author{
Орловская А.И. \\ Центр исследования проблем российского права «Эквитас» \\ Москва, Россия
}

doi: 10.18411/lj2016-7-1-16

idsp 000001: lj2016-16-1-16

\section{Резервист: военнослужащий или наемный работник?}

Гарантированное обеспечение военной безопасности и территориальной целостности России невозможно без развертывания боеспособных группировок войск (сил) с привлечением военно-обученных мобилизационных людских ресурсов. В целях перехода на перспективный облик Вооруженных Сил Российской Федерации была создана новая система подготовки и накопления мобилизационных людских резервов (далее - также резерв).

Однако устойчивое функционирование новой системы в условиях формирования нового облика российской армии невозможно без научного осмысления теоретико-правовых основ статуса военнослужащих, в том числе и правового статуса граждан, пребывающих в мобилизационном людском резерве (далее - резервистов).

Поддерживая выводы отдельных ученых о том, что одно и то же лицо может быть одновременно носителем различных правовых статусов в зависимости от занимаемых им социальных позиций, можно утверждать, что правовой статус резервистов основан на общем статусе гражданина, а специальный - на общем правовом статусе военнослужащих, и, отражая особенности положения граждан, пребывающих в мобилизационном людском резерве, имеет свою специфику, дополнительные права, обязанности, льготы, предусмотренные законодательством.

Однако, если «правовое положение личности, или иначе, юридический статус человека и гражданина в обществе и государстве, представляет собой 
сложный и многосторонний конституционно-правовой институт», то особенности правового статуса резервиста относятся к институту военного права, субъектами которого они выступают, реализуя свой служебный статус в военно-правовых отношениях. Следовательно, вполне обоснован вывод о том, что правовой статус резервиста в теории военного права как самостоятельной комплексной отрасли российского права представляет собой институт указанной отрасли.

Некоторые вопросы пребывания граждан в мобилизационном людском резерве частично уже отражены в отдельных нормативных правовых актах, в частности, общие вопросы поступления граждан в резерв, пребывания в резерве и увольнения из резерва, вопросы призыва граждан на военные сборы и прохождения гражданами военных сборов в период пребывания в запасе, проведение мероприятий по медицинскому освидетельствованию и медицинскому обследованию для граждан, поступающих в резерв, но детальное изучение нормативных актов по вопросу пребывания граждан в резерве так и не дает правоприменителю ответа, кто же такие резервисты: военнослужащие или «гражданские»?

Пребывание граждан Российской Федерации в мобилизационном людском резерве разделяется на два периода: прохождение военных сборов и пребывание в запасе.

В соответствии с п. 15 Положения о проведении военных сборов, утвержденного постановлением Правительства Российской Федерации от 29 мая 2006 г. № 333 «О военных сборах и некоторых вопросах обеспечения исполнения воинской обязанности» граждане, проходящие военные сборы, считаются исполняющими обязанности военной службы. Принципом законодательства о военной службе и статусе военнослужащих является строго обязательное и в полном объеме исполнение военнослужащими возложенных на них служебных обязанностей. Какого-либо изъятия из этого правила для военнослужащих не предусмотрено.

Проблемы распространения статуса военнослужащих на граждан, пребывающих в запасе, ранее были рассмотрены в работах К.В.Фатеева, С.В. Корнишина, Р.А. Закирова. 
Вышеперечисленные авторы поднимали вопросы о несовершенстве статуса граждан, пребывающих в запасе, опосредованном несовершенством регламентирующего его законодательства.

Следует поддержать научную точку зрения от том, что на граждан, пребывающих в запасе, «статус военнослужащих не может распространяться на них во всем своем объеме... в отношении них можно говорить лишь о некоторых правах, обязанностях и частично - ответственности военнослужащих в случаях и порядке, которые предусмотрены федеральными законами и иными нормативными правовыми актами Российской Федерации».

Одновременно нельзя не согласиться с мнениями А.В. Кудашкина, Л.Л. Попова, Ю.И. Мигачева, С.В. Тихомирова, которые указывают, что по совокупности признаков, гражданин, призванный на военные сборы, в полной мере соответствует статусу военнослужащего, и, следовательно, проходит военную службу. Это означает на период прохождения военных сборов резервист проходит военную службу, поскольку назначается на воинскую должность, у него сохраняется его воинское звание, ему выплачивается денежное довольствие, исходя из оклада денежного содержания военнослужащего.

Анализ законодательства позволяет выделить отдельные элементы, присущие только военной службе.

1. Так, резервисту как гражданину, пребывающему в запасе, может быть присвоено воинское звание. А согласно п. 2 ст. 1 Положения о порядке прохождения военной службы, утвержденного указом Президента Российской Федерации от 16 сентября 1999 г. № 1237 «Вопросы прохождения военной службы» (далее - Положение о порядке прохождения военной службы) включает в себя присвоение воинского звания, а также другие обстоятельства (события) (назначение на воинскую должность, аттестацию, увольнение с военной службы) с которыми в соответствии с законодательством определяется служебно-правовое положение военнослужащих. Отсюда следует, что присвоение воинского звания - это элемент исключительно прохождения военной службы и вне военной службы существовать не может. Это подтверждает п. 1 ст. 22 Положения о порядке прохождения военной службы, который гласит, что очередное воинское звание присваивается 
военнослужащему в день истечения срока его военной службы в предыдущем воинском звании, если он занимает воинскую должность (должность), для которой штатом предусмотрено воинское звание, равное или более высокое, чем воинское звание, присваиваемое военнослужащему.

2. Поступление в мобилизационные людские резервы Вооруженных Сил Российской Федерации, других войск, воинских формирований и органов осуществляется на добровольной основе путем заключения контракта о пребывании в резерве. Согласно абз. 2 п. 1 ст. 2 Федерального закона Российской Федерации от 27 мая 1998 г. № 76-Ф3 «О статусе военнослужащих» к военнослужащим относятся офицеры, прапорщики и мичманы... сержанты и старшины, солдаты и матросы, проходящие военную службу по контракту. Таким образом, пребывание в резерве непременно связано с наличием такого юридического факта, характерного в том числе и для военной службы, как заключение контракта.

3. Пунктом 3 статьи 57.2 Федерального закона «О воинской обязанности и военной службе» предусмотрено, что одно из условий контракта о пребывании в резерве включает в себя право гражданина на получение социальных гарантий и компенсаций, установленных федеральными законами и иными нормативными правовыми актами Российской Федерации. Как и для военнослужащих, проходящих военную службу по контракту, законодателем предусмотрено установление денежных выплат резервистам как при прохождении военных сборов, так и в период пребывания в запасе, то есть в течение срока действия контракта о пребывании в резерве. То есть можно утверждать, что гарантии и компенсации, входящие в структуру правового статуса резервиста, являются одновременно элементом, присущим военной службе.

На основании изложенного можно сделать вывод, что для пребывания резервиста в резерве характерны отдельные элементы, присущие именно военной службе, но возложение на него прав и обязанностей военнослужащего противоправно.

Таким образом, вполне обоснован вывод об уникальности статуса резервиста и недопустимости приравнивания его к той или иной социальной группе. Ни статус военнослужащих, ни статус граждан, призванных на военные сборы не могут распространяться на них в полном объеме. 
С учетом задач Вооруженных Сил Российской Федерации, других войск, воинских формирований и органов большое значение имеет детальное определение правового положения их личного состава. Поэтому важно, в частности, обеспечить в нормативных актах должный учет обстоятельств, влияющих на правовое положение личного состава, включая граждан, пребывающих в мобилизационном людском резерве.

Обеспечению надлежащей определенности пребывания в мобилизационном людском резерве, могла бы способствовать, в частности, регламентация правового положения резервистов в соответствующем документе, например, в федеральном законе «О статусе граждан, пребывающих в мобилизационном людском резерве».

В системе современного законодательства Российской Федерации предлагаемый закон будет регулировать права, свободы, обязанности и ответственность граждан, пребывающих в резерве, с учетом законодательного разделения состава запаса Вооруженных Сил Российской Федерации, запаса Службы внешней разведки Российской Федерации и запаса Федеральной службы безопасности Российской Федерации, которые предназначены для укомплектования соединений, воинских частей Вооруженных Сил Российской Федерации, других войск, воинских формирований и органов, а также специальных формирований в период мобилизации, приведения их в боевую готовность и в военное время. 


\section{Литература:}

1. Витрук Н.В. Основы теории правового положения личности в социалистическом обществе. М., 1979. С. 186.

2. Воеводин Л. Д. Юридический статус личности в России. - М, МГУ; ИНФРА-М-Норма. 1997. С. 27.

3. Вопросы прохождения военной службы : указ Президента Рос. Федерации от 16 сентября 1999 г. № 1237 // Собр. законодательства Рос. Федерации. - 1999. - № 39, ст. 4590.

4. Закиров Р.А. Правомерно ли присвоение воинских званий гражданам пребывающим в запасе? // Право в Вооруженных Силах, 2010, № 9, C.86-88.

5. Корнишин С.В. Можно ли считать военнослужащими граждан, призванных на военные сборы? // Российская юстиция. 1999. № 12. С. 21.

6. Корнишин С.В. О некоторых вопросах распространения статуса военнослужащих на граждан, призванных на военные сборы // Право в Вооруженных Силах, 1999 г., № 11. С 59-60.

7. Корякин В.М. Введение в теорию военного права: монография. // Право в Вооруженных Силах - консультант. М. : За права военнослужащих. 2006. - Вып. 9. URL: http://voenprav.ru/doc-3922-1.htm.

8. Корякин В.М. Теоретико-правовые основы статуса ветерана в Российской Федерации // Рос. воен.-правовой сб. 2007. № 9. С. 270.

9. Кудашкин А.В., Фатеев К.В. Комментарий к Федеральному закону «О статусе военнослужащих». - М.: «За права военнослужащих», 2009. ИПС «ГаранТ».

10. Новоселов В.И. Правовое положение граждан в советском государственном управлении. Саратов, 1976. С. 28 
11. О воинской обязанности и военной службе : федер. закон Рос. Федерации от 28 марта 1998 г. № 53-Ф3: принят Гос. Думой Федер. Собрания Рос. Федерации 6 марта 1998 г. :одобр. Советом Федерации Федер. Собрания Рос. Федерации 12 марта 1998 г. : в ред. федер. закона Рос. Федерации от 25 ноября 2012 г. № 317-Ф3 // Собр. законодательства Рос. Федерации. - 1998. - № 13, ст.1475.

12. О военных сборах и некоторых вопросах обеспечения исполнения воинской обязанности (вместе с Положением о проведении военных сборов): постановление Правительства Рос. Федерации от 29 мая 2006 г. № 333: с изм. от 28 октября 2013 г. № 964 // Собр. законодательства Рос. Федерации. - 2006. - № 23, ст. 2525.

13. О внесении изменений в отдельные законодательные акты Российской Федерации по вопросам создания мобилизационного людского резерва : федер. закон от 30 декабря 2012 г. № 288-Ф3 : принят Гос. Думой 18 декабря 2012 г. : одобр. Советом Федерации Федер. Собр. Рос. Федерации 26 декабря 2012 г. // Собр. Законодательства Рос. Федерации. - 2013. - № 1, ст. 213.

14. О мобилизационной подготовке и мобилизации в Российской Федерации : федер. закон Рос. Федерации от 26 февраля 1997 г. № 31Ф3: принят Гос. Думой Федер. Собрания Рос. Федерации 24 января 1997 г. :одобр. Советом Федерации Федер. Собрания Рос. Федерации 13 февраля 1997 г. : в ред. федер. закона Рос. Федерации от 5 апреля 2013 г № 55-Ф3 // Собр. законодательства Рос. Федерации. - 1997. - № 9, ст.1014.

15. Орловская А.И. Теоретико-правовые основы правового статуса резервиста при нахождении в мобилизационном людском резерве в мирное время // Военное право: электронный журнал. - 2014.- Вып. 1. URL: http://www.voennoepravo.ru/node/5268. 
16. Орловская А.И., Шурыгина Ю.А. Элементы правового статуса резервиста при нахождении в мобилизационном людском резерве в мирное время / А.И. Орловская, Ю.А. Шурыгина // Проблемы и перспективы развития современной юриспруденции : сборник научных трудов по итогам научно-практической конференции от 8 дек. 2014 г. : Воронеж, Инновационный центр развития образования и науки, 2014. C. 110 .

17. О статусе военнослужащих : федер. закон Рос. Федерации № 76-ФЗ от 27 мая 1998 г. : принят Гос. Думой Федер. Собрания Рос. Федерации 06 марта 1998 г. : одобр. Советом Федерации Федер. Собрания Рос. Федерации 12 марта 1998 г. : по сост. на 5 июня 2013 г. // Собр. законодательства Рос. Федерации - 1998. - № 22, ст. 2331.

18. Патюлин В.А. Государство и личность в СССР. М., 1974. С. 198 - 199.

19. Положение о порядке пребывания граждан Российской Федерации в мобилизационном людском резерве: постановление Правительства Рос. Федерации от 3 сентября 2015 г. № 933 : п. 42 // Собр. законодательства Рос. Федерации. - 2015. - № 37, ст. 5147.

20. Попов Л.Л., Мигачев Ю.И., Тихомиров С.В. Административное право России: учебник /отв. ред. Попов Л.Л. - М.: Проспект, 2010. - С. 279

21. Трудовой Кодекс Российской Федерации: федер. закон Рос. Федерации от 30 декабря 2001 г. № 197-Ф3: принят Гос. Думой Федер. Собрания Рос. Федерации 21 декабря 2001 г. :одобр. Советом Федерации Федер. Собрания Рос. Федерации 26 декабря 2001 г. : в ред. федер. закона Рос. Федерации от 3 июля 2016 г. № 347-Ф3: ст. 124 // Собр. законодательства Рос. Федерации. - 2002. - № 1 (ч. 1), ст. 3.

22. Фатеев К.В. О военных сборах и правовом статусе граждан, пребывающих в запасе, во время прохождения военных сборов // Право в Вооруженных Силах 2008, № 8, С. 30-43. 